\title{
GENETIC DIVERGENCE AMONG COTTON GENOTYPES GROWN IN THE MAIN SEASON AND OFF SEASON ${ }^{1}$
}

\author{
THIAGO ALEXANDRE SANTANA GILIO²*, DEJÂNIA VIEIRA DE ARAÚJO ${ }^{3}$, WILLIAN KRAUSE ${ }^{3}$, HUGO \\ HENRIQUE RIBEIRO ROSA ${ }^{3}$, JOÃO PAULO ASCARI ${ }^{3}$
}

\begin{abstract}
The objective of this work was to evaluate the agronomic performance and estimate the genetic divergence of 18 cotton genotypes grown in the main season (sowed in December, 2012) and off season (sowed in January, 2013), considering their agronomic characteristics and resistance to Ramularia leaf spot. A randomized block experimental design was used, with five replications. The characteristics evaluated were plant height, first branch height, position of first fruiting branch, height of first fruiting branch, length between nodes, number of nodes, average number of bolls per plant, average boll weight, area under the disease progress curve (AUDPC) related to the Ramularia leaf spot severity, weight of 100 -seed from the plant middle third, fiber percentage, average production per plant, yield and cotton fiber quality. The results were subjected to individual and joint analysis of variance and the genetic divergence was estimated according to multivariate procedures (Mahalanobis' generalized distance and Tocher's optimization method). The dissimilarity matrices were summed to estimate the genetic divergence, considering both growing periods. Genetic variability was found among the genotypes evaluated, in both the main season and off season. The characteristic that most contributed to the genetic divergence in the main season was the production per plant and, in the off season, was the fiber percentage. According to the results of the present work, the crosses between the genotypes BRS-335 and FMT-707; FM-910 and FMT-707; and IMA-08-12427 and FMT-707 are recommended.
\end{abstract}

Keywords: Agronomic characteristics. Ramularia leaf spot. Gossypium hirsutum L.. Mahalanobis' generalized distance. Tocher's optimization method.

\section{DIVERGÊNCIA GENÉTICA EM GENÓTIPOS DE ALGODÃO EM CONDIÇÕES DE SAFRA E SAFRINHA}

\begin{abstract}
RESUMO - O objetivo deste trabalho foi avaliar o comportamento agronômico e estimar a divergência genética entre 18 genótipos de algodeiro, com base em características agronômicas e de resistência à mancha de ramulária. O delineamento experimental foi em blocos ao acaso com cinco repetições, em duas épocas de plantio, sendo em safra (dezembro de 2012) e safrinha (janeiro de 2013). As características avaliadas foram: altura da planta, altura do primeiro ramo, posição do primeiro ramo frutífero, altura do primeiro ramo frutífero em centímetros, comprimento entre nós, número de nós, número médio de capulhos por planta, peso médio por capulho, área abaixo da curva de progresso da severidade da mancha de ramulária (AACPS), peso de cem sementes no terço médio, porcentagem de fibra, produção média por planta, produtividade e as caracteristicas tecnológicas da fibra do algodão.Foi realizada a análise de variância individual e conjunta das características avaliadas e estimada a divergência genética com base nos procedimentos multivariados de distância generalizada de Mahalanobis e o método de agrupamento de otimização de Tocher. Para estimar a divergência genética considerando as duas safras, as matrizes de dissimilaridade foram somadas. Houve variabilidade genética entre os genótipos testados, tanto em condições de safra como de safrinha. As características que mais contribuíram para a divergência genética foram a produção por planta na safra e a porcentagem de fibra na safrinha. Com os resultados deste trabalho sugere-se cruzamentos entre os genótipos BRS 335 e FMT 707, FM 910 e FMT 707, IMA 08-12427 e FMT 707.
\end{abstract}

Palavras-chave: Características Agronomicas. Mancha de ramulária. Gossypium hirsutum L.. Distância generalizada de Mahalanobis. Otimização de Tocher.

\footnotetext{
*Corresponding author

${ }^{1}$ Received for publication in $08 / 02 / 2015$; accepted in 08/19/2016.

Paper extract from the master thesis of the first author.

${ }^{2}$ Department of Agronomy, Universidade Estadual de Maringá, Maringá, PR, Brazil; thiago_gilio@hotmail.com.

${ }^{3}$ Department of Agronomy, Universidade do Estado de Mato Grosso, Tangará da Serra, MT, Brazil; dejania@unemat.br, krause@unemat.br,hugo_henriquerr@hotmail.com, joaoascari@hotmail.com.
} 


\section{INTRODUCTION}

Cotton belongs to the Malvaceae family, whose genus Gossypium has more than 50 native species in arid and semi-arid regions of the Americas, Asia, Africa and Australia, of which 45 are diploid $(2 \mathrm{n}=26)$ and 5 allotetraploids $(2 \mathrm{n}=52)$ (FANG et al., 2013; TYAGI et al., 2014).

However, only four cotton species are commercially cultivated, of which two are diploid ( $G$. arboreum L. and G. herbaceum L.) and two allotetraploids ( $G$. hirsutum L. and $G$. barbadense L.). The species $G$. hirsutum has shown higher levels of genetic variability than the other three species (WENDEL et al., 1992; ABDURAKHMONOV et al., 2008). However, the genetic basis of $G$. hirsutum, from which derives the existing cultivars, is considered restricted and that variability is not present in these cotton cultivars (IQBAL et al., 2001; MOIANA et al., 2015).

Brazil is the fifth largest producer of cotton, which had a production of 1.275 million $\mathrm{Mg}$ of raw cotton in 2012 (FAO, 2012). However, some diseases affect the economic growth of this crop. Ramularia leaf spot (Ramularia areola G. F. Atk.) is considered the cotton main disease, which may compromise more than $36 \%$ of the yield and decrease the cotton fiber resistance (GILIO, 2014).

In addition to the resistance to diseases, several economic characteristics must be considered by the plant breeder to obtain a commercial cultivar, such as yield, boll and seed weight, fiber percentage, fiber quality, resistance to pest and plant architecture (CIA; SALGADO, 2005; FARIAS et al., 2008).

The variability between the parent plants has great importance to achieve a constant improvement of these characteristics in a population. The absence of genetic variability of the parent materials used for breeding limits the obtaining of promising lines (VILELA-MORALES; VALOIS, 2000).

The plant variability can be assessed by the quantification of genetic divergence, through agronomic and morphological characters and molecular markers. Regarding the quantitative agronomic characters, the variability can be assessed through dissimilarity measures, such as the Euclidean distance and Mahalanobis' generalized distance (CRUZ; CARNEIRO, 2003; CRUZ; REGAZZI; CARNEIRO, 2012).

The preference for the Mahalanobis' generalized distance is because this method takes into account the residual variances and covariance between the characteristics evaluated, thus needing an experimental design (CRUZ; CARNEIRO 2003; CRUZ; REGAZZI; CARNEIRO, 2012).

The use of agronomic characters and multivariate techniques is common for plant breeding of different crops, such as maize (MORO; SILVEIRA; CARGNELUTTI FILHO, 2007, CARDOSO et al., 2009; SIMON; KAMADA; MOITEIRO, 2012; MIRANDA, 2003), common bean (ELIAS et al., 2007; BARELLI et al., 2009; CORREA; GONÇALVES, 2012), castor bean (RODRIGUES et al., 2010) and cassava (ZUIN et al., 2009).

According to Hallauer and Miranda Filho (1981), in addition to the high genetic divergence, the plant performance related to the desired characteristics in the desired environment is greatly important for choose the plant parents, in order to successfully obtaining superior lines.

The objective of this work was to evaluate the agronomic performance and estimate the genetic divergences of 18 cotton genotypes grown in the main season (sowed in December, 2012) and off season (sowed in January, 2013), considering their agronomic characteristics and resistance to Ramularia leaf spot.

\section{MATERIAL AND METHODS}

\section{Experimental area}

The experiments were conducted in the experimental field of the Mato Grosso State University (UNEMAT), Tangara da Serra campus $\left(14^{\circ} 39^{\prime} 0^{\prime \prime} \mathrm{S}, 5^{\circ} 26^{\prime} 0^{\prime \prime} \mathrm{W}\right.$ and altitude of $\left.320 \mathrm{~m}\right)$. The region has annual average temperature of $24,4^{\circ} \mathrm{C}$, annual average precipitation of $1,500 \mathrm{~mm}$ and relative humidity of $70-80 \%$, with rainfall concentrated in October to March, and a dry season in April to September (DALLACORT et al., 2011).

\section{Experimental design and materials}

Two experiments were conducted with different sowing times, December, 2012 (main season) and January, 2013 (off season). A randomized block experimental design was used with 18 treatments (genotypes) (Table 1) with five replications. Among the chosen genotypes are the main cultivars cropped in Brazil.

Each experimental plot consisted of a 5-meter row, with seven plants per meter. The rows were spaced $0.90 \mathrm{~m}$ apart. The experiments had border rows of the cultivar Nuopal.

Fertilization was performed according to the chemical analysis results and recommendations by Souza and Lobato (2004). Insect pest and weed control were performed according to the technical recommendations for the culture. 
T. A. S. GILIO et al.

Table 1. Cotton genotypes used in the experiments and their breeders.

\begin{tabular}{|c|c|c|c|}
\hline Number & Name & Genotype & Breeder \\
\hline 1 & FiberMax-966LL & Cultivar & Bayer Seeds \\
\hline 2 & FiberMax-975WS & Cultivar & Bayer Seeds \\
\hline 3 & FiberMax-951LL & Cultivar & Bayer Seeds \\
\hline 4 & FiberMax-910 & Cultivar & Bayer Seeds \\
\hline 5 & $I M A-07-6035$ & Improved lineage* & Mato Grosso Cotton Institute \\
\hline 6 & IMA-08-12427 & Improved lineage* & Mato Grosso Cotton Institute \\
\hline 7 & $I M A-09-474$ & Improved lineage* & Mato Grosso Cotton Institute \\
\hline 8 & $I M A-09-2059$ & Improved lineage* & Mato Grosso Cotton Institute \\
\hline 9 & $B R S-335$ & Cultivar & Embrapa \\
\hline 10 & $B R S-336$ & Cultivar & Embrapa \\
\hline 11 & $F M T-705$ & Cultivar & Mato Grosso Fundation \\
\hline 12 & $F M T-709$ & Cultivar & Mato Grosso Fundation \\
\hline 13 & $F M T-707$ & Cultivar & Mato Grosso Fundation \\
\hline 14 & $I A C-09-848$ & Improved lineage* & Agronomic Institute of Campinas \\
\hline 15 & $I A C-08-2031$ & Improved lineage* & Agronomic Institute of Campinas \\
\hline 16 & Nuopal & Cultivar & Delta Pine \\
\hline 17 & Nuopal-RR & Cultivar & Delta Pine \\
\hline 18 & $D P-555-B G R R$ & Cultivar & Delta Pine \\
\hline
\end{tabular}

*material in test phase, not yet registered.

\section{Agronomic characterization}

\section{A - Resistance to Ramularia leaf spot}

The Ramularia leaf spot disease occurred naturally. The symptoms were observed 65 days after planting, when the weekly evaluations started, which continued up to the $128^{\text {th }}$ day after planting. The Ramularia leaf spot severity was evaluated using the diagrammatic scale proposed by Aquino et al. (2008). This scale consists of nine severity levels ranging from $0.05 \%$ to $67.20 \%$ of area injured by the disease, in which $1=0.05 \%, 2=0.50 \%, 3=1.00 \%$, $4=2.00 \%, 5 \%=4.00,6=8.00 \%, \quad 7=16.00 \%$, $8=32.00 \%$ and $9=67.20 \%$. The Ramularia leaf spot severity values were used to calculate the area under the disease progress curve (AUDPC) (SHANER;

FINNEY, 1977):

$$
\text { AUDPC }=\sum_{i=1}^{n-1}\left(\frac{N_{i}+N_{i+1}}{2}\right)\left(t_{i+1}-t_{i}\right)
$$

where $n$ is the number of evaluations, $N$ is the Ramularia leaf spot severity and $t_{i+1}-t_{i}$ is the interval between two evaluations.

\section{B - Plant architecture and production}

\section{characteristics}

The agronomic characteristics evaluated were plant height $(\mathrm{PH})$ from the base to the apex $(\mathrm{cm})$; first branch height $(\mathrm{FBH})$ from the base to the first branch $(\mathrm{cm})$; position of first fruiting branch (PFFB) (cm); height of first fruiting branch (HFFB) from the base to the first fruiting branch $(\mathrm{cm})$; length between nodes $(\mathrm{LBN})(\mathrm{cm})$; number of nodes $(\mathrm{NN})$; average number of bolls per plant (ANBP); average boll weight $(\mathrm{ABW})$, average weight of all bolls of six plants $(\mathrm{g})$; 100-seed weight from the plant middle third (100SW), average of 100 seeds of six plants $(\mathrm{g})$; fiber percentage $(\mathrm{F} \%)$ from 20 bolls from the middle third of each plant; average production per plant (APP), average from the seed cotton production (g) of each plant; and yield (Y), cotton seed production $(\mathrm{g})$ from each plot converted to $\mathrm{Kg} \mathrm{ha}^{-1}$. All variables were assessed in six plants per plot, except the yield.

\section{C - Cotton fiber quality}

The fiber characteristics evaluated were length (UHM), uniformity index (UI), resistance 
index (STR), elongation (ELG), micronaire (MIC), fiber reflectance (RD), yellowness level $(+B)$, maturity (MR), short fiber index (SFI) and count strength index (CSP). For the fiber analyses fifty grams of cotton fiber were collected in five points of the total fiber mass of each plot, totaling 250 grams per plot. All fiber analyses were performed in a HVI (High Volume Instrument) device by the Kuhlmann Laboratory, in Sapezal, Mato Grosso (MT), Brazil.

\section{Data analysis}

The data of the characteristics evaluated were subjected to individual and joint analysis of variance and when significant, the means of the production characteristics were subjected to the Scott-Knott test at $5 \%$ probability. The homogeneity between growing periods was assessed by calculating the maximum F, as described by Cruz, Regazzi and Carneiro (2012). The genotypic coefficient of determination $\left(\mathrm{h}^{2}\right)$, was estimated by the genotypic and residue mean squares. The genetic divergence was assessed by the method of Mahalanobis' generalized distance $\left(\mathrm{D}^{2}\right)$ (MAHALANOBIS, 1936). Similar groups were determined by the Tocher's optimization method and the unweighted pair group method with arithmetic mean (UPGMA). The dissimilarity matrices were summed for the Tocher's optimization method and UPGMA to estimate the genetic divergence considering both growing periods. The correlation between the dissimilarity matrices of the main season, off season and joint periods was carried out using the methodology suggested by Mantel (1967), with 10,000 permutations. The validation of the UPGMA grouping was performed using the cophenetic correlation coefficient (CCC) (SOKAL; ROHLF, 1962). Analyses of variance and all multivariate analyzes were performed in the software Genes (CRUZ, 2006) and dendograms were generated using the software Mega-5.2 (TAMURA et al., 2011).

\section{RESULTS AND DISCUSSION}

The variance analysis of the experiment conducted in the main season showed significant differences between the genotypes averages for most of the characteristics evaluated (Table 2).

The experiment conducted in the off season showed significant differences between the genotypes for the characteristics first branch height $(\mathrm{FBH})$, elongation $(\mathrm{ELG})$, yellowness level $(+\mathrm{B})$ and maturity (MR). The coefficient of variation of the characteristics evaluated ranged from 1.14\% (MR) to $28.04 \%$ for the area under the disease progress curve (AUDPC) in the main season, and from $0.57 \%$ for the uniformity index (UI) to $23.12 \%$ (AUDPC) in the off season. The coefficient of variation for most variables was relatively low in both growing periods (Table 2).

Most of the genotypic coefficient of determination was higher in the off season, which ranged from $50.0 \%$ to 97.94 , while in the main season, it ranged from $30.09 \%$ to $96.93 \%$. Thus, the off season may be better for parent selection. For example, the genotypic coefficient of determination was higher for the AUDPC in the off season, indicating that the off season period evaluated is better for selecting this characteristic. This result may be related to the water stress that usually occurs in the off season (ECHER et al., 2010) and to the intensity of the $R$. areola inoculum, which is greater in the off season due to the various development cycles of the pathogen, denoting that Ramularia leaf spot occurs earlier in the off season.

The fiber reflectance (RD) and count strength index (CSP) were the only characteristics that presented no homogeneity of residual variances, with maximum calculated $F$ of 7.16 and 7.98, respectively. The interaction between genotypes and growing periods (main season and off season) was significant for most of the agronomic characteristics evaluated, except the fiber characteristics ELG, RD, yellowness level $(+\mathrm{B}), \mathrm{MR}$ and CSP, indicating that the genotype performance is dependent on the growing periods (Table 3 ). The coefficient of variation in the joint analysis was low for most of the characteristics evaluated, ranging from $1.07 \%$ to $25.85 \%$ (Table 3). Hoogerheide et al. (2007) evaluated eight cotton genotypes in different regions of the Mato Grosso State (MT), Brazil, and found significant interaction between the genotypes and environment, indicating that the genotype results had no consistency in the different locations.

The variables related to production are shown in Table 4, whose average values formed two groups for the main season, as well as for the off season. The genotypes BRS-335, FM-910, FM-951, 705-FMT, FMT-707, FMT-709, IMA-08-12427 and IMA-09-474 had the highest productions in both growing periods. The genotypes BRS-336, FMT-705 and IMA-08-12427 in the main season and the FMT-709 and BRS-336 in the off season presented the highest fiber percentage $(\mathrm{F} \%)$.

The genotypes Nuopal-RR and IAC-08-2031 had the greatest average boll weight (ABW) in the off season (Table 4). On the other hand, the ABW of the 18 genotypes differed in only two groups in the main season, in which the the genotypes $B R S-336$, FM-951-LL-, FM-966, FMT-705, IMA-07-6035 and IMA-08-12427 had the lower values.

The average number of bolls per plant (ANBP) ranged from 5.87 to 9.80 in the main season and from 3.34 to 6.15 in the off season. The highest ANPB were presented by the genotype IMA-08-12427 in the main season and the IMA-09-2059 in the of-season (Table 4). 
T. A. S. GILIO et al.

Table 2. Individual analysis of variance of the 23 agronomic and fiber characteristics of 18 cotton genotypes grown in the main season and off season.

\begin{tabular}{|c|c|c|c|c|c|c|c|c|c|c|}
\hline & \multicolumn{5}{|c|}{ Main season } & \multicolumn{5}{|c|}{ Off season } \\
\hline & \multicolumn{3}{|c|}{ Mean square } & \multirow[b]{2}{*}{$\mathrm{CV}$} & \multirow[b]{2}{*}{$\mathrm{h}^{2}$} & \multicolumn{3}{|c|}{ Mean square } & \multirow[b]{2}{*}{$\mathrm{CV}$} & \multirow[b]{2}{*}{$h^{2}$} \\
\hline & Block & Genotype & Residue & & & Blocks & Genotype & Residue & & \\
\hline $\mathrm{PH}$ & 10.72 & $54.86^{* *}$ & 15.47 & 6.07 & 78.0 & 107.36 & $173.74^{* *}$ & 53.93 & 8.37 & 76.31 \\
\hline FBH & 1.45 & $2.1 * *$ & 1.11 & 7.91 & $65 . \hat{4}$ & 1.41 & $1.06^{\mathrm{ns}}$ & 0.80 & 17.27 & 59.99 \\
\hline PFFB & 1.14 & $1.11^{* *}$ & 0.19 & 5.58 & 85.3 & 0.91 & $1.79^{* *}$ & 0.46 & 10.81 & 79.56 \\
\hline HFFB & 32.02 & $19.67 * *$ & 5.91 & 8.07 & 79.9 & 6.96 & $49.70 * *$ & 16.11 & 16.22 & 75.52 \\
\hline LBN & 0.15 & $0.34^{\mathrm{ns}}$ & 0.79 & 7.22 & 30.0 & 0.37 & $0.74 * *$ & 0.18 & 10.93 & 80.43 \\
\hline $\mathrm{NN}$ & 1.78 & $1.76^{* *}$ & 0.45 & 4.04 & 79.6 & 1.43 & $11.47 * *$ & 1.15 & 5.07 & 90.89 \\
\hline ANBP & 0.15 & $4.37 * *$ & 0.18 & 6.06 & 96.0 & 0.15 & $1.90 * *$ & 0.04 & 4.23 & 97.94 \\
\hline ABW & 0.07 & $0.57^{*}$ & 0.10 & 7.65 & 85.0 & 0.15 & $1.45^{* *}$ & 0.06 & 7.07 & 96.03 \\
\hline AUDPC & 20956 & $25368 * *$ & 6896 & 28.04 & 78.6 & 7096 & $179544^{* *}$ & 9544 & 23.12 & 94.95 \\
\hline $100 \mathrm{SW}$ & 3.12 & $1.00^{\mathrm{ns}}$ & 1.92 & 16.11 & 34.2 & 14.54 & $402.01^{* *}$ & 31.18 & 5.45 & 92.80 \\
\hline $\mathrm{F} \%$ & 0.26 & $10.28^{* *}$ & 0.81 & 2.05 & 92.7 & 0.12 & $9.98^{* *}$ & 0.32 & 1.34 & 96.89 \\
\hline APP & 0.68 & $72.91 * *$ & 2.54 & 5.76 & 96.6 & 0.70 & $7.99^{* *}$ & 0.74 & 5.09 & 91.52 \\
\hline Yield & 26967 & $217169^{* *}$ & 80286 & 21.09 & 73.0 & 11439 & $31190^{* *}$ & 12756 & 16.03 & 70.97 \\
\hline UHM & 2.01 & $1.65^{* *}$ & 0.67 & 2.94 & 71.1 & 0.02 & $1.34^{* *}$ & 0.25 & 1.91 & 84.28 \\
\hline UI & 1.90 & $2.20^{\mathrm{ns}}$ & 1.34 & 1.39 & 62.1 & 0.29 & $1.52 * *$ & 0.21 & 0.57 & 87.86 \\
\hline STR & 3.07 & $1.69^{\mathrm{ns}}$ & 1.17 & 3.59 & 59.0 & 0.61 & $2.59 * *$ & 0.77 & 3.15 & 77.08 \\
\hline ELG & 0.01 & $0.04 * *$ & 0.01 & 1.73 & 80.0 & 0.10 & $0.03^{\mathrm{ns}}$ & 0.03 & 2.91 & 50.00 \\
\hline MIC & 0.03 & $0.16^{\mathrm{ns}}$ & 0.11 & 8.03 & 59.2 & 0.01 & $0.10^{* *}$ & 0.03 & 4.95 & 76.92 \\
\hline $\mathrm{RD}$ & 4.53 & $4.60^{\mathrm{ns}}$ & 4.66 & 3.05 & 49.6 & 1.13 & $1.95^{* *}$ & 0.65 & 1.10 & 75.00 \\
\hline$+\mathrm{B}$ & 0.60 & $0.49^{\mathrm{ns}}$ & 0.52 & 9.41 & 48.5 & 3.27 & $0.61^{\mathrm{ns}}$ & 0.48 & 8.31 & 55.96 \\
\hline MR & 0.00 & $0.0001^{\mathrm{ns}}$ & 0.0001 & 1.14 & 50.0 & 0.0001 & $0.0002^{\mathrm{ns}}$ & 0.0001 & 1.32 & 66.67 \\
\hline SFI & 2.28 & $2.39^{*}$ & 1.09 & 10.71 & 68.6 & 0.09 & $2.63 * *$ & 0.49 & 5.74 & 84.29 \\
\hline CSP & 39467 & $62010^{\mathrm{ns}}$ & 55167 & 9.06 & 52.9 & 3031 & $71596^{* *}$ & 6908.94 & 3.71 & 91.20 \\
\hline
\end{tabular}

** significant at $1 \%$ by the $\mathrm{F}$ test; $*$ significant at $5 \%$ by the $\mathrm{F}$ test; $\mathrm{ns}=$ not significant; $\mathrm{h}^{2}=$ genotypic coefficient of determination; $\mathrm{CV}=$ coefficient of variation; Agronomic characteristics: $\mathrm{PH}=$ plant height; $\mathrm{FBH}=$ first branch height; PFFB = position of first fruiting branch; HFFB = height of first fruiting branch; LBN = length between nodes; $\mathrm{NN}=$ number of nodes; ANBP = average number of bolls per plant; ABW = average boll weight; $100 \mathrm{SW}=100-\mathrm{Seed}$ weight in the middle third; F\% = fiber percentage; APP = average production per plant and Yield. Fiber technological characteristics: $\mathrm{UHM}=$ length; UI = uniformity index; STR = resistance index; ELG = elongation; MIC = micronaire; $\mathrm{RD}=$ fiber reflectance; $+\mathrm{B}=$ yellowness level; $\mathrm{MR}=$ maturity; $\mathrm{SFI}=$ short fiber index and $\mathrm{CSP}=$ Count Strength Index.

Table 3. Joint analysis of variance of the 23 agronomic and fiber characteristics of 18 cotton genotypes grown in the main season and off season.

\begin{tabular}{|c|c|c|c|c|c|c|c|}
\hline & \multicolumn{5}{|c|}{ Mean square } & \multirow[b]{2}{*}{ Means } & \multirow[b]{2}{*}{$\mathrm{CV}(\%)$} \\
\hline & Block & Genotypes & Seasons & $\begin{array}{l}\text { Genotypes X } \\
\text { Seasons }\end{array}$ & Residue & & \\
\hline PH & 54.65 & $126.70 * *$ & $23667.43 * *$ & $101.89 * *$ & 35.52 & 76.24 & 7.82 \\
\hline FBH & 0.63 & $1.67 * *$ & $208.12^{* *}$ & $1.52 * *$ & 0.62 & 6.26 & 12.54 \\
\hline PFFB & 0.60 & $0.60 *$ & $97.40 * *$ & $2.30 * *$ & 0.36 & 7.05 & 8.51 \\
\hline HFFB & 15.16 & $34.17^{* *}$ & $1299.43 * *$ & $35.20 * *$ & 11.37 & 27.43 & 12.30 \\
\hline LBN & 0.42 & $0.72 * *$ & $0.10^{\mathrm{ns}}$ & $0.36^{* *}$ & 0.13 & 3.90 & 9.26 \\
\hline $\mathrm{NN}$ & 2.02 & $6.56^{* *}$ & $874.77 * *$ & $6.67 * *$ & 0.82 & 18.95 & 4.77 \\
\hline ANBP & 0.29 & $3.40 * *$ & $225.14^{* *}$ & $2.87 * *$ & 0.11 & 5.86 & 5.58 \\
\hline $\mathrm{ABW}$ & 0.21 & $1.13 * *$ & $18.41 * *$ & $0.89 * *$ & 0.07 & 3.80 & 7.36 \\
\hline AUDPC & 5476.6 & $147771.6^{* *}$ & $719876.10^{* *}$ & $57140.98 * *$ & 8630.91 & 359.41 & 25.85 \\
\hline 100SW & 9.56 & $201.38 * *$ & $396713.42 * *$ & $201.64 * *$ & 30.05 & 55.56 & 9.86 \\
\hline $\mathrm{F} \%$ & 0.27 & $11.95 * *$ & $120.92 * *$ & $8.30 * *$ & 0.56 & 43.34 & 1.72 \\
\hline
\end{tabular}

** significant at $1 \%$ by the $\mathrm{F}$ test; * significant at $5 \%$ by the $\mathrm{F}$ test; $\mathrm{ns}=$ not significant; $\mathrm{CV}=$ coefficient of variation; Agronomic characteristics: $\mathrm{PH}=$ plant height; $\mathrm{FBH}=$ first branch height; PFFB = position of first fruiting branch; $\mathrm{HFFB}=$ height of first fruiting branch; $\mathrm{LBN}=$ length between nodes; $\mathrm{NN}=$ number of nodes; ANBP = average number of bolls per plant; $\mathrm{ABW}=$ average boll weight; $100 \mathrm{SW}=100$-Seed Weight in the middle third; $\mathrm{F} \%=$ fiber percentage; $\mathrm{APP}=$ average production per plant and Yield. Fiber technological characteristics: UHM = length; UI = uniformity index; $\mathrm{STR}=$ resistance index; $\mathrm{ELG}=$ elongation; $\mathrm{MIC}=$ micronaire; $\mathrm{RD}=$ fiber reflectance $+\mathrm{B}=$ yellowness level; $\mathrm{MR}=$ maturity; SFI $=$ short fiber index and CSP $=$ Count Strength Index. 
T. A. S. GILIO et al.

Table 3. Continuation.

\begin{tabular}{|c|c|c|c|c|c|c|c|}
\hline & \multicolumn{5}{|c|}{ Mean square } & \multirow[b]{2}{*}{ Means } & \multirow[b]{2}{*}{$\mathrm{CV}(\%)$} \\
\hline & Block & Genotypes & Seasons & $\begin{array}{l}\text { Genotypes X } \\
\text { Seasons }\end{array}$ & Residue & & \\
\hline APP & 0.86 & $42.69^{* *}$ & $5240.92 * *$ & $38.22 * *$ & 1.60 & 22.31 & 5.69 \\
\hline Yield & 27595 & $145136.4^{* *}$ & $18394118.6^{* *}$ & $103222.9 * *$ & 45501.3 & 1024.13 & 20.83 \\
\hline UHM & 1.15 & $1.73 * *$ & $126.13^{* *}$ & $1.26^{* *}$ & 0.47 & 27.04 & 2.54 \\
\hline UI & 1.24 & $2.07 * *$ & $213.57 * *$ & $1.65 * *$ & 0.78 & 82.13 & 1.07 \\
\hline STR & 2.70 & $2.10 * *$ & $220.82 * *$ & $2.18 * *$ & 0.97 & 29.07 & 3.40 \\
\hline ELG & 0.06 & $0.03^{\mathrm{ns}}$ & $1.02 * *$ & $0.04^{\mathrm{ns}}$ & 0.02 & 6.53 & 2.43 \\
\hline MIC & 0.03 & $0.07^{\mathrm{ns}}$ & $7.61 * *$ & $0.19 * *$ & 0.07 & 3.96 & 6.76 \\
\hline $\mathrm{RD}$ & 2.91 & $1.89^{\text {ns }}$ & $257.40 * *$ & $4.66^{\mathrm{ns}}$ & 4.27 & 72.05 & 2.87 \\
\hline$+\mathrm{B}$ & 2.21 & $0.62^{\mathrm{ns}}$ & $19.12 * *$ & $0.47^{\mathrm{ns}}$ & 0.53 & 7.98 & 9.12 \\
\hline MR & 0.0009 & $0.0001^{\mathrm{ns}}$ & $0.018^{* *}$ & $0.0002^{\mathrm{ns}}$ & 0.0001 & 0.82 & 1.22 \\
\hline SFI & 2.12 & $2.74 * *$ & $258.70 * *$ & $2.28 * *$ & 0.80 & 10.97 & 8.17 \\
\hline CSP & 16132 & $55453.39^{\text {ns }}$ & $5487688.48 * *$ & $78152.90^{\text {ns }}$ & 50902.2 & 2416.79 & 9.33 \\
\hline
\end{tabular}

** significant at $1 \%$ by the $\mathrm{F}$ test; * significant at $5 \%$ by the $\mathrm{F}$ test; $\mathrm{ns}=$ not significant; $\mathrm{CV}=$ coefficient of variation; Agronomic characteristics: $\mathrm{PH}=$ plant height; FBH $=$ first branch height; PFFB = position of first fruiting branch; $\mathrm{HFFB}=$ height of first fruiting branch; LBN = length between nodes; NN = number of nodes; ANBP = average number of bolls per plant; $\mathrm{ABW}=$ average boll weight; $100 \mathrm{SW}=100$-Seed Weight in the middle third; $\mathrm{F} \%=$ fiber percentage; APP = average production per plant and Yield. Fiber technological characteristics: UHM = length; UI = uniformity index; $\mathrm{STR}=$ resistance index; $\mathrm{ELG}=$ elongation; $\mathrm{MIC}=$ micronaire; $\mathrm{RD}=$ fiber reflectance $+\mathrm{B}=$ yellowness level; $\mathrm{MR}=$ maturity; $\mathrm{SFI}=$ short fiber index and CSP $=$ Count Strength Index.

The AUDPC index related to the Ramularia leaf spot ranged from 180.02 to 448.61 in the main season, differentiating the genotypes into two groups of averages, in which the FMT-705, BRS-335, BRS-336, DP-555BGRR, FM-951LL, FM-975WS, FMT-707, FMT-709, IAC-08-2031, IAC-09-848, IMA-07-6035, IMA-08-12427 and IMA-09-474 had the lowest AUDPC index, thus, they were considered the most resistant in this experiment. The genotypes were grouped into four groups in the off season, in which the FMT-707 and FMT-705, IAC-09-848 and IMA08-12427 had the lowest AUDPC index, thus, they were considered the most resistant (Table 4). Cia et al. (2013) also identified the genotype
FMT-705 as resistant and the FM-966-LL as susceptible in an experiment conducted in Primavera do Leste MT, Brazil, however, the same authors identified the genotype FM-966- $L L$ as resistant in an experiment conducted in Ribeirao Preto, Sao Paulo (SP), Brazil, result that was different from that found in the present work, in which the FM-966- $L L$ was identified as susceptible. Cia et al. (2008) evaluated 16 cotton genotypes for resistance to diseases in the 2003/2004 crop season, in Primavera do Leste MT, and Acreúna, Parana (PR), Brazil, and reported the genotype FM-966, an isoline of the genotype FM-966- $L L$ as resistant to Ramularia leaf spot.

Table 4. Characteristics related to production and response to Ramularia leaf spot of 18 cotton genotypes grown in the main season and off season.

\begin{tabular}{lcccccc}
\hline & \multicolumn{2}{c}{ Yield } & \multicolumn{2}{c}{ APP $(\mathrm{g})$} & \multicolumn{2}{c}{ ANBP } \\
\cline { 2 - 6 } Genotypes & Main season & Off season & Main season & Off season & Main season & Off season \\
\hline BRS-335 & $1617.1 \mathrm{a}$ & $730.1 \mathrm{a}$ & $23.5 \mathrm{e}$ & $17.5 \mathrm{a}$ & $5.9 \mathrm{e}$ & $5.2 \mathrm{~b}$ \\
$B R S-336$ & $1334.5 \mathrm{~b}$ & $631.0 \mathrm{~b}$ & $28.4 \mathrm{c}$ & $14.8 \mathrm{~b}$ & $7.6 \mathrm{c}$ & $4.6 \mathrm{c}$ \\
$D P 555 B G R R$ & $976.49 \mathrm{~b}$ & $684.4 \mathrm{a}$ & $27.4 \mathrm{~d}$ & $14.7 \mathrm{~b}$ & $7.0 \mathrm{c}$ & $4.8 \mathrm{c}$ \\
$F M-910$ & $1606.3 \mathrm{a}$ & $700.7 \mathrm{a}$ & $36.4 \mathrm{a}$ & $16.6 \mathrm{a}$ & $8.2 \mathrm{~b}$ & $5.2 \mathrm{~b}$ \\
$F M-951 L L$ & $1535.3 \mathrm{a}$ & $684.5 \mathrm{a}$ & $26.0 \mathrm{e}$ & $17.0 \mathrm{a}$ & $7.3 \mathrm{c}$ & $4.8 \mathrm{c}$ \\
$F M-966 L L$ & $988.1 \mathrm{~b}$ & $773.9 \mathrm{a}$ & $24.5 \mathrm{e}$ & $17.8 \mathrm{a}$ & $6.5 \mathrm{~d}$ & $5.0 \mathrm{~b}$ \\
$F M-975 W S$ & $1212.8 \mathrm{~b}$ & $626.4 \mathrm{~b}$ & $27.6 \mathrm{~d}$ & $17.3 \mathrm{a}$ & $6.1 \mathrm{e}$ & $5.0 \mathrm{~b}$ \\
$F M T-705$ & $1143.7 \mathrm{~b}$ & $792.0 \mathrm{a}$ & $22.4 \mathrm{e}$ & $17.3 \mathrm{a}$ & $6.1 \mathrm{e}$ & $5.1 \mathrm{~b}$ \\
$F M T-707$ & $1454.4 \mathrm{a}$ & $758.3 \mathrm{a}$ & $31.1 \mathrm{~b}$ & $17.8 \mathrm{a}$ & $7.1 \mathrm{c}$ & $5.2 \mathrm{~b}$ \\
$F M T-709$ & $1499.3 \mathrm{a}$ & $785.8 \mathrm{a}$ & $23.7 \mathrm{e}$ & $13.5 \mathrm{~b}$ & $6.0 \mathrm{e}$ & $3.8 \mathrm{e}$ \\
$I A C-08-2031$ & $1241.9 \mathrm{~b}$ & $532.1 \mathrm{~b}$ & $29.2 \mathrm{c}$ & $17.1 \mathrm{a}$ & $7.3 \mathrm{c}$ & $4.2 \mathrm{~d}$ \\
\hline
\end{tabular}

Means followed by the same letter in the column do not differ significantly by the Scott-Knott test at $5 \%$ probability. Agronomic characteristics: Yield; APP = average production per plant; ANBP = average number of bolls per plant $\mathrm{ABW}=$ average boll weight and $\mathrm{F} \%=$ fiber percentage; $\mathrm{AUDPC}=$ Area under the disease progress curve. 
T. A. S. GILIO et al.

Table 4. Continuation.

\begin{tabular}{|c|c|c|c|c|c|c|}
\hline \multirow[b]{2}{*}{ Genotypes } & \multicolumn{2}{|c|}{ Yield } & \multicolumn{2}{|c|}{ APP (g) } & \multicolumn{2}{|c|}{ ANBP } \\
\hline & Main season & Off season & Main season & Off season & Main season & Off season \\
\hline$I A C-09-848$ & $1145.8 b$ & $635.8 \mathrm{~b}$ & $26.7 d$ & $17.4 \mathrm{a}$ & $6.7 \mathrm{~d}$ & $4.5 \mathrm{~d}$ \\
\hline$I M A-07-6035$ & $1238.4 b$ & $711.5 \mathrm{a}$ & $24.5 \mathrm{e}$ & $17.7 \mathrm{a}$ & $7.1 \mathrm{c}$ & $4.6 \mathrm{c}$ \\
\hline$I M A-08-12427$ & $1674.8 \mathrm{a}$ & $810.3 a$ & $35.5 \mathrm{a}$ & $17.2 \mathrm{a}$ & $9.8 \mathrm{a}$ & $4.9 \mathrm{c}$ \\
\hline IMA-09-2059 & $1356.4 \mathrm{~b}$ & $696.3 \mathrm{a}$ & $29.8 \mathrm{c}$ & $18.0 \mathrm{a}$ & $6.6 \mathrm{~d}$ & $6.1 \mathrm{a}$ \\
\hline IMA-09-474 & $1512.9 \mathrm{a}$ & $790.8 \mathrm{a}$ & $25.9 \mathrm{e}$ & $17.0 \mathrm{a}$ & $6.6 \mathrm{~d}$ & $4.3 \mathrm{~d}$ \\
\hline Nuopal & $1285.5 b$ & $755.5 \mathrm{a}$ & $29.2 \mathrm{c}$ & $18.0 \mathrm{a}$ & $7.3 \mathrm{c}$ & $4.7 \mathrm{c}$ \\
\hline \multirow[t]{2}{*}{ NuopalRR } & $1364.6 \mathrm{~b}$ & $580.9 \mathrm{~b}$ & $26.7 d$ & $17.6 \mathrm{a}$ & $6.5 \mathrm{~d}$ & $3.3 \mathrm{f}$ \\
\hline & \multicolumn{2}{|c|}{ ABW } & \multicolumn{2}{|c|}{$\mathrm{F} \%$} & \multicolumn{2}{|c|}{ AUDPC } \\
\hline Genotypes & Main season & Off season & Main season & Off season & Main season & Off season \\
\hline$B R S-335$ & $4.2 \mathrm{a}$ & $3.0 \mathrm{f}$ & $43.5 \mathrm{c}$ & $41.6 \mathrm{f}$ & $283.8 \mathrm{a}$ & $677.1 \mathrm{~d}$ \\
\hline$B R S-336$ & $3.7 \mathrm{~b}$ & $3.2 \mathrm{e}$ & $46.6 \mathrm{a}$ & $44.9 b$ & $262.3 \mathrm{a}$ & $265.6 b$ \\
\hline DP555BGRR & $4.1 \mathrm{a}$ & $3.0 \mathrm{f}$ & $42.2 \mathrm{~d}$ & $43.8 \mathrm{c}$ & $278.0 \mathrm{a}$ & $570.6 \mathrm{c}$ \\
\hline$F M-910$ & $4.4 \mathrm{a}$ & $3.0 \mathrm{f}$ & $44.4 \mathrm{~b}$ & $42.9 \mathrm{~d}$ & $374.7 \mathrm{~b}$ & $643.8 \mathrm{~d}$ \\
\hline$F M-951 L L$ & $3.6 \mathrm{~b}$ & $3.3 \mathrm{e}$ & $44.5 b$ & $44.1 \mathrm{c}$ & $252.2 \mathrm{a}$ & $461.7 \mathrm{c}$ \\
\hline$F M-966 L L$ & $3.8 \mathrm{~b}$ & $3.5 \mathrm{~d}$ & $42.9 c$ & $42.3 \mathrm{e}$ & $442.2 \mathrm{~b}$ & $598.3 d$ \\
\hline$F M-975 W S$ & $4.6 \mathrm{a}$ & $3.3 \mathrm{e}$ & $41.8 \mathrm{~d}$ & $41.8 \mathrm{e}$ & $287.8 \mathrm{a}$ & $501.1 \mathrm{~b}$ \\
\hline FMT-705 & $3.8 \mathrm{~b}$ & $3.2 \mathrm{e}$ & $47.1 \mathrm{a}$ & $42.9 \mathrm{~d}$ & $180.0 \mathrm{a}$ & $179.1 \mathrm{a}$ \\
\hline FMT-707 & $4.4 \mathrm{a}$ & $3.0 \mathrm{f}$ & $44.3 b$ & $42.7 \mathrm{~d}$ & $259.3 \mathrm{a}$ & $118.0 \mathrm{a}$ \\
\hline$F M T-709$ & $4.2 \mathrm{a}$ & $4.0 \mathrm{c}$ & $44.5 b$ & $45.7 \mathrm{a}$ & $244.7 \mathrm{a}$ & $309.8 b$ \\
\hline$I A C-08-2031$ & $4.1 \mathrm{a}$ & $4.4 \mathrm{~b}$ & $44.0 \mathrm{~b}$ & $42.2 \mathrm{e}$ & $244.8 \mathrm{a}$ & $321.6 \mathrm{~b}$ \\
\hline$I A C-09-848$ & $4.1 \mathrm{a}$ & $3.9 \mathrm{c}$ & $44.0 \mathrm{~b}$ & $42.1 \mathrm{e}$ & $217.5 \mathrm{a}$ & $204.5 \mathrm{a}$ \\
\hline$I M A-07-6035$ & $3.7 \mathrm{~b}$ & $3.8 \mathrm{c}$ & $44.7 b$ & $40.9 \mathrm{f}$ & $284.0 \mathrm{a}$ & $552.6 \mathrm{c}$ \\
\hline IMA-08-12427 & $3.7 \mathrm{~b}$ & $3.3 \mathrm{e}$ & $45.7 \mathrm{a}$ & $40.7 f$ & $284.5 \mathrm{a}$ & $198.7 \mathrm{a}$ \\
\hline$I M A-09-2059$ & $4.4 \mathrm{a}$ & $2.7 \mathrm{f}$ & $43.6 \mathrm{c}$ & $40.7 f$ & $344.0 \mathrm{~b}$ & $630.8 \mathrm{c}$ \\
\hline IMA-09-474 & $4.7 \mathrm{a}$ & $3.8 \mathrm{c}$ & $44.7 b$ & $41.0 \mathrm{f}$ & $291.5 \mathrm{a}$ & $241.7 \mathrm{~b}$ \\
\hline Nuopal & $4.2 \mathrm{a}$ & $3.6 \mathrm{~d}$ & $41.8 \mathrm{~d}$ & $42.2 \mathrm{e}$ & $448.6 b$ & $614.5 \mathrm{~d}$ \\
\hline NuopalRR & $4.5 \mathrm{a}$ & $4.7 \mathrm{a}$ & $44.3 b$ & $43.0 \mathrm{~d}$ & $350.8 \mathrm{~b}$ & $518.3 \mathrm{c}$ \\
\hline
\end{tabular}

Means followed by the same letter in the column do not differ significantly by the Scott-Knott test at $5 \%$ probability. Agronomic characteristics: Yield; APP = average production per plant; ANBP = average number of bolls per plant; $\mathrm{ABW}=$ average boll weight and $\mathrm{F} \%=$ fiber percentage; $\mathrm{AUDPC}=$ Area under the disease progress curve.

The characteristic that presented the highest relative contribution, regarding the genetic divergence in the main season, were the average production per plant (APP) $(18.15 \%)$, followed by the ANBP (12.71\%), height of first fruiting branch (HFFB) $(11.79 \%)$ and F\% (8.99\%). On the other hand, in the off season, the characteristics that most contributed to the genetic divergence were the $\mathrm{F} \%$ (17.86\%), ANBP (15.27\%), number of nodes (NN) $(11.15 \%)$ and AUDPC (10.76\%) (Table 5). The result of each characteristic was dependent on the period in which the experiment was conducted, thus, experiments in the off season may be more efficient for selecting genotypes with some characteristics, such as resistance to Ramularia leaf spot, since the contribution to the AUDPC divergence was significantly higher in the off season. The same dependence was observed for the agronomic characteristics, for which the main season may be more efficient for selecting superior genotypes regarding some characteristics, such as the APP, ANBP, HFFB and F\%.

Table 5. Relative contribution of the characteristics of 18 cotton genotypes, grown in the main season and off season, for the genetic divergence by the method of Singh (1981), based on the Mahalanobis' generalized distance.

\begin{tabular}{lccc}
\hline & & \multicolumn{2}{c}{ Relative contribution (\%) } \\
\cline { 1 - 1 } Characteristics & & Main season & Off season \\
Plant height & & 2.74 & 1.89 \\
First branch height & 4.37 & 0.62 \\
Position of first fruiting branch & 8.09 & 0.78 \\
Height of first fruiting branch & 11.79 & 4.19 \\
\hline
\end{tabular}


T. A. S. GILIO et al.

Table 5. Continuation.

\begin{tabular}{lcc}
\hline & \multicolumn{2}{c}{ Relative contribution (\%) } \\
\cline { 3 - 3 } \cline { 3 - 3 } Characteristics & Main season & Off season \\
\cline { 3 - 3 } Number of nodes & 8.71 & 0.26 \\
Average number of bolls per plant & 0.51 & 11.15 \\
Average boll weight & 12.71 & 15.27 \\
AUDPC & 3.02 & 8.76 \\
100-Seed Weight & 0.96 & 10.76 \\
Fiber \% & 0.16 & 5.86 \\
Average production per plant & 8.98 & 17.86 \\
Yield & 18.15 & 4.05 \\
Fiber length & 1.18 & 1.64 \\
Uniformity index & 3.53 & 0.67 \\
Resistance index & 4.06 & 4.09 \\
Fiber elongation & 0.96 & 1.05 \\
Micronaire & 3.27 & 0.36 \\
Fiber reflectance & 0.69 & 2.69 \\
Yellowness level & 0.50 & 1.96 \\
Fiber maturity & 0.59 & 0.99 \\
Short fiber index & 1.87 & 0.61 \\
Count Strength index & 1.36 & 0.59 \\
\hline
\end{tabular}

The grouping analysis by the Tocher's optimization method formed five groups for both growing periods, however, the genotypes contained in each group were different. In the main season, one group of twelve genotypes, one of two genotypes, and three of one genotype were formed. In the off season, one group of eight genotypes, one of six genotypes, one of two genotypes and two of one genotype were formed (Table 6).

Based on the grouping analysis by the Tocher's optimization method, the interbreeding between the genotypes FMT-707 and IMA-09-474 is recommended to obtaining promising linages for the main season, due to their genetic distant, good yield performances, resistance to Ramularia leaf spot and $\mathrm{F} \%$. The interbreeding between the genotypes FMT-707 and IMA-09-2059 is recommended for the off season, since both present good yield performances. Thus, the IMA-09-2059 shows no resistance to Ramularia leaf spot, while the FMT-707 may be used in breeding programs as a source of this characteristic. The differences in the similarity groups formed may be due to biotic and abiotic stress, such as the Ramularia leaf spot and especially the weather. Simon, Kamada and Moiteiro (2012) evaluated the genetic divergence of popcorn maize hybrids and also found differences in the similarity groups formed in the main season and off season.

Table 6. Grouping of 18 cotton genotypes by the Tocher's optimization method, based on the Mahalanobis' generalized distance $\left(\mathrm{D}^{2}\right)$, considering 23 agronomic characteristics, in the main season and off season.

\begin{tabular}{|c|c|}
\hline & Main season \\
\hline Groups & Genotypes \\
\hline I & $\begin{array}{l}I A C-09-848, F M T-707, \text { Nuopal-RR, BRS-335, IMA-07-6035, FMT-705, BRS-336, IAC-08-2031, DP-555- } \\
\text { BG-RR, IMA-09-2059, FM-975-WS and Nuopal }\end{array}$ \\
\hline II & $F M-910, I M A-08-12427$ and $F M 951 L L$ \\
\hline III & FMT-709 \\
\hline IV & IMA-09-474 \\
\hline \multirow[t]{2}{*}{$\mathrm{V}$} & $F M-966-L L$ \\
\hline & Off season \\
\hline Groups & Genotypes \\
\hline I & BRS-335, FM-966-LL, Nuopal, FM-910, FM-951-LL, DP-555-BG-RR, FMT-705 e FMT 707. \\
\hline II & IMA-08-12427, IMA-09-474, IMA-07-6035, FM-975-WS, IAC-09-848 and IAC 08-205I. \\
\hline III & $B R S-336$ and FTM-709 \\
\hline IV & Nuopal-RR \\
\hline V & IMA-09-2059 \\
\hline
\end{tabular}


The UPGMA method formed two groups in the main season, considering the cutoff point at 40 , with the Group I consisting of three subgroups (subgroup I: Fibermax-951-LL, IAC-09-848, BRS-336, IAC-08-2031, BRS-335, FMT-709, FMT-705, IMA-07-6035, Fibermax-966-LL,
DP-555-BG-RR, Fibermax-975-WS, Nuopal, IMA-09-2059 and Nuopal-RR; subgroup II: IMA-09-474 and subgroup III: FMT-707) and Group II consisting of two genotypes (Fibermax-910 and IMA-08-12427) (Figure 1).

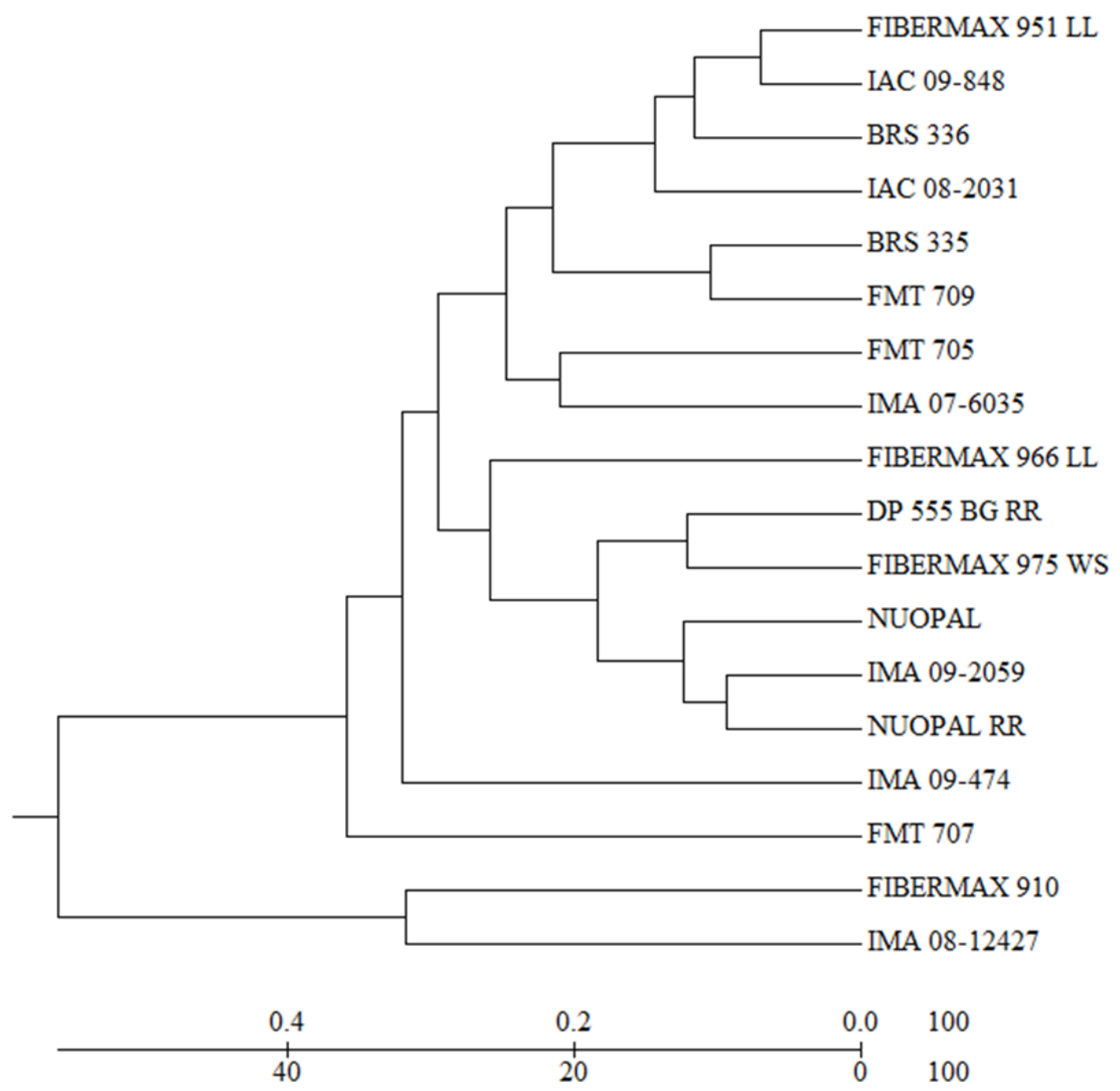

Figure 1. Dendrogram of the dissimilarity patterns established by the unweighted pair group method with arithmetic mean (UPGMA), using quantitative data of 18 cotton genotypes sowed in the main season and off season. (Cophenetic Correlation Coefficient $\mathrm{CCC}=0.72, \mathrm{p}<0.01,10,000$ permutations).

The UPGMA method formed five groups in the off season, considering the cutoff point at 50 , with the Group I consisting of six genotypes (BRS-335, Fibermax-966, Nuopal, IMA-07-6035, Fibermax-975-WS, IMA-09-2059), Group II consisting of six genotypes (FMT-705, FMT-707, BRS-336, Fibermax-910, DP-555-BG-RR and Fibermax-951-LL), Group III consisting of four genotypes (IAC-08-2031, IAC-09-474, IAC-09-848, IMA-09-12427 and IMA-09-474), and Group IV (FMT-709) and V (Nuopal-RR) consisting of one genotype (Figure 2).

Krause et al. (2009) evaluated the genetic divergence and resistance to Curtobacterium wilt in pod-bean and the genetic divergence presented consistent results using the UPGMA method based on the Mahalanobis' generalized distance. This grouping method has been used in several studies on different crops, such as maize (SIMON; KAMADA; MOITEIRO, 2012), popcorn maize (MIRANDA, 2003), common bean (BARELLI et al., 2009) and castor bean (RODRIGUES et al., 2010), estimating satisfactorily the genetic divergence.

The two grouping methods, Tocher and UPGMA, presented different results for the main season, off season and when considering both growing periods. Suinaga, Bastos and Rangel (2005) estimated the divergence in cotton accessions and found similarity between both methods, differently from the results found in the present work.

The use of the UPGMA method combined with the Tocher's optimization method, for evaluations of dissimilarity, can ensure a greater certitude in estimating the genetic divergence of genotypes (ELIAS et al., 2007; ZUIN et al., 2009; SIMON; KAMADA; MOITEIRO, 2012). 


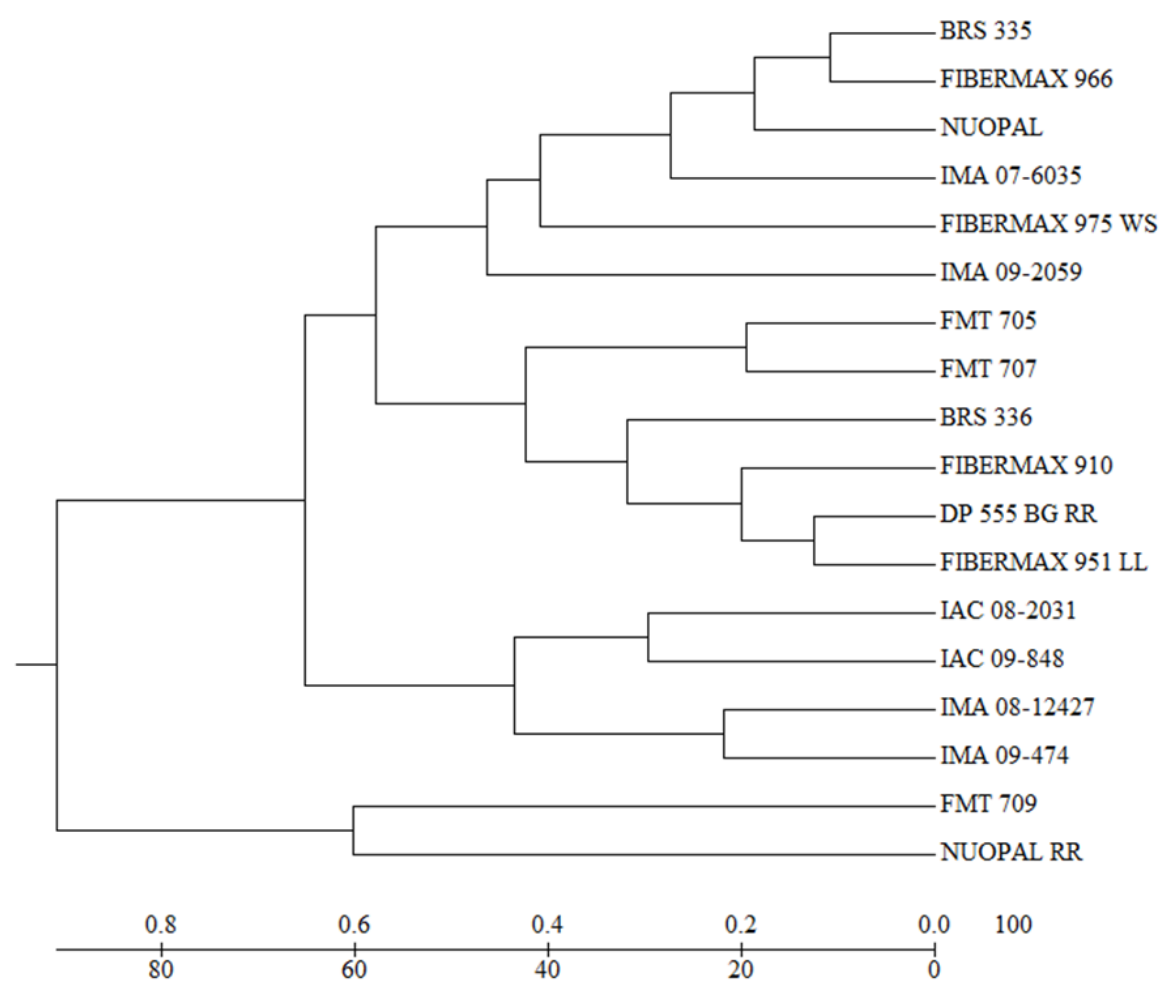

Figure 2. Dendrogram of the dissimilarity patterns established by the unweighted pair group method with arithmetic mean (UPGMA), using quantitative data of 18 cotton genotypes sowed in the main season and off season. (Cophenetic Correlation Coefficient $\mathrm{CCC}=0.69, \mathrm{p}<0.01,10,000$ permutations).

The correlation between the dissimilarity matrices of the main season and off season was not significant, which is another indication of heterogeneity in the response of the genotypes to the different growing periods. The correlation between the joint matrix and the mains season, and joint matrix and off season, showed a significant result $(\mathrm{p}<0.01)$ by the Mantel test, with similar amplitudes (0.7282 and 0.7284 , respectively) (Table 7).

The lack of correlation between the main season and off season (Table 7) indicates that the variability achieved in the off season cannot be achieved in the mains season, thus the need for genetic divergence studies in both periods.

The evaluation of the divergence in both growing periods is important for lower the possibility of getting misinformation, since the environmental variability have to be considered in these studies. (CARGNELUTTI FILHO et al., 2008).

Table 7. Correlation between dissimilarity matrices of the main season, off season and joint periods.

\begin{tabular}{lcc}
\hline & Main season & Off season \\
\hline Joint periods & $0.7282^{* *}$ & $0.7284^{* *}$ \\
Off season & $0.0639^{\mathrm{ns}}$ & \\
\hline
\end{tabular}

**Significant at $1 \%$ by the Mantel test; $\mathrm{ns}=$ not significant.

Considering both growing periods by the sum of the Mahalanobis dissimilarity matrices, the Tocher's optimization method formed seven groups of genotypes, Group I (FM-910, FM-951-LL, Nuopal, DP-555-BG-RR, BRS-335 and FM-975-WS), Group II (IAC-09-848, IMA-07-6035, IAC-08-2031, IMA-09-474 and Nuopal-RR), Group III (BRS-336 and FMT-709), Group IV (FMT-705 and FMT-707), Group V (FM-966-LL), Group VI (IMA-08-12427) and Group VII (IMA-09-2059) (Table 8). Based on the divergence assessed in both growing periods, the interbreeding between the FM-910 or BRS-335 and FMT-707 are recommended. These are not the the most genetically distant genotypes, but they had good performances related to production characteristics, and the genotype FMT-707 was among the most resistant to Ramularia leaf spot. 
T. A. S. GILIO et al.

Table 8. Grouping of 18 cotton genotypes by the Tocher's optimization method, based on the Mahalanobis' generalized distance $\left(\mathrm{D}^{2}\right)$, considering 23 agronomic characteristics, in the main season and off season.

\begin{tabular}{ll}
\hline Groups & Genotypes \\
\hline I & FM-910, FM-951 LL, Nuopal, DP-555-BG-RR, BRS-335 and FM-975-WS \\
II & IAC-09-848, IMA-07-6035, IAC-08-2031, IMA-09-474 and Nuopal-RR \\
III & BRS-336 and FMT-709 \\
IV & FMT-705 and FMT-707 \\
V & FM-966-LL \\
VI & $I M A-08-12427$ \\
VII & $I M A-09-2059$ \\
\hline
\end{tabular}

The dendrogram developed by the UPGMA method, considering both growing periods (Figure 3), formed five groups, considering the cutoff point at 80, Group I consisting of six genotypes (BRS-335, Fibermax-966-LL, Nuopal, IMA-07-6035, Fibermax-975-LL, IMA-09-2059), Group II consisting of six genotypes (FMT-705 and FMT-707, Fibermax-910, DP-555-BG-RR, BRS-336 and Fibermax-951-LL), Group III consisting of one genotype (IMA-08-12427), Group IV consisting of three genotypes (IMA-09-474, IAC-08-2031 and $I A C-09-848)$, and Group $\mathrm{V}$ consisting of two genotypes (FMT-709 and Nuopal-RR). Based on the dendrogram, which illustrate the pattern dissimilarity by the UPGMA method, crosses between genotypes BRS-335 and FMT-709 or IMA-08-12427 are recommended, since they are divergent and have good performances of production and resistance to Ramularia leaf spot.

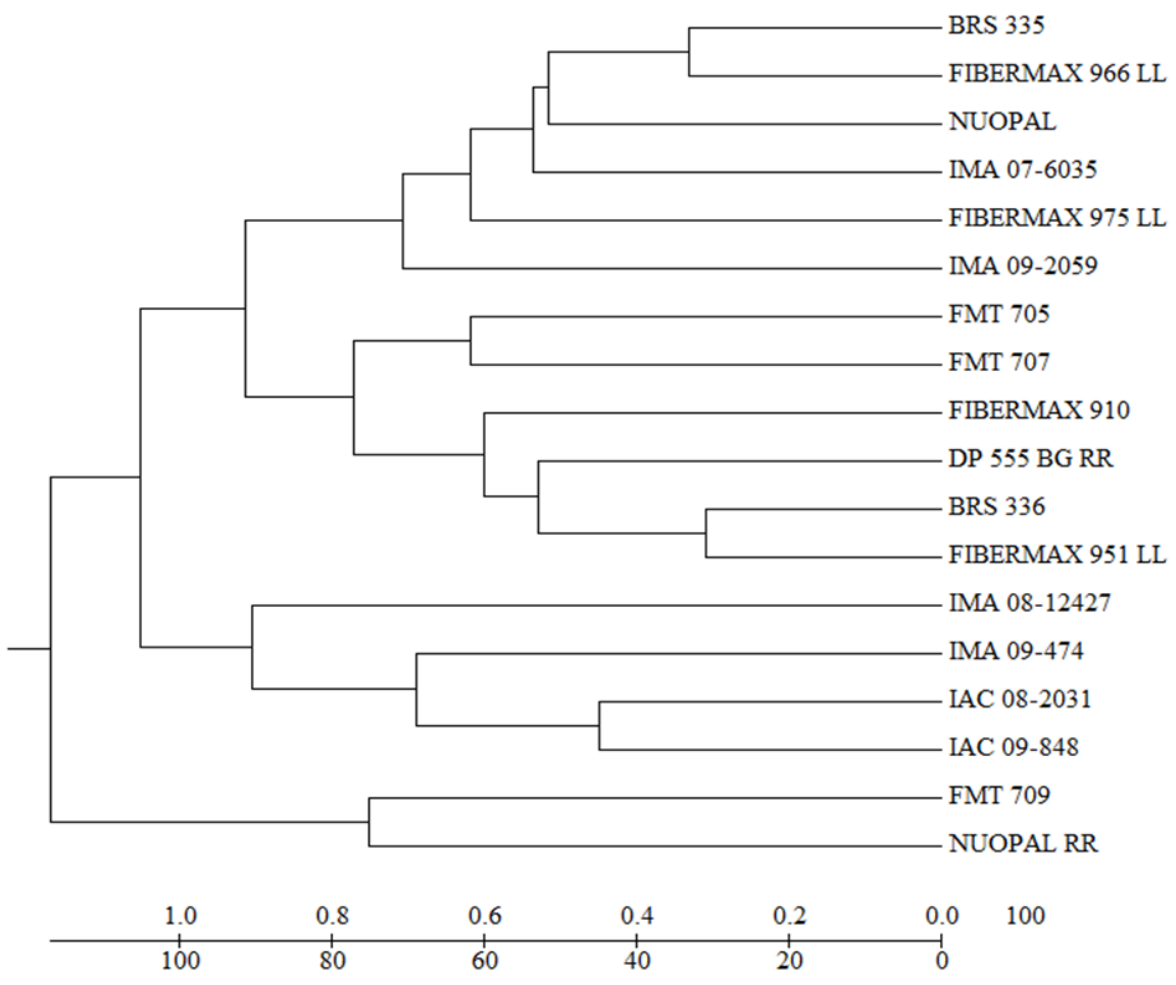

Figure 3. Dendrogram of the dissimilarity patterns established by the unweighted pair group method with arithmetic mean (UPGMA), using quantitative data of 18 cotton genotypes sowed in the main season and off season. (Cophenetic Correlation Coefficient $\mathrm{CCC}=0.68, \mathrm{p}<0.01,10,000$ permutations).

The Cophenetic Correlation Coefficient (CCC) for the dendrogram, which illustrate the pattern dissimilarity by the UPGMA method, was 0.72 for the main season, 0.69 for the off season and
0.68 for the joint periods (main season and off season) (Figures 1, 2 and 3). These CCC values are considered adequate, since values equal to or higher than 0.56 are considered ideals (VAZ PATTO et al., 
2004), indicating that the dendograms obtained by the UPGMA method satisfactorily reproduces the information contained in the dissimilarity matrix.

\section{CONCLUSIONS}

The genotypes FMT-707, FMT-705, IAC-09848 and IMA-08-12427 were the most resistant to Ramularia leaf spot in both growing periods evaluated (main season and off season), and can be used as sources of resistance to this disease in breeding programs.

The genetic variability found among the 18 cotton genotypes used in this study is sufficient to start a cotton breeding program.

The evaluation of cotton genotypes in different periods (main seasons and off season) provided a better assessment of the genetic variability, since the variability assessed in this work in main season was different than the variability accessed in the off season.

\section{ACKNOWLEDGEMENTS}

The authors thank the researcher D.Sc. Edvaldo Cia from the Agronomic Institute of Campinas for providing the cotton seeds, the Kuhlmann's laboratory (Sapezal MT) personnel for their kindness in the fiber technological analysis, the Vanguarda Group (Nova Mutum MT) personnel for their help in the cotton ginning, and the Mato Grosso State Research Support Foundation (FAPEMAT) for granting the master's scholarship to the first author.

\section{REFERENCES}

ABDURAKHMONOV, I. Y. et al. Molecular Diversity and Association Mapping of Fiber Quality Traits in Exotic G. hirsutum L. Germplasm. Genomics, Boston, v. 92, n. 6, p. 478-487, 2008.

AQUINO, L. A. et al. Elaboração e validação de escala diagramática para a quantificação da mancha de ramulária do algodoeiro. Summa Phytopathologica, Botucatu, v. 34, n. 4, p. 361-363. 2008.

BARELLI, M. A. et al. Divergência genética em cultivares tradicionais de feijão do estado de Mato Grosso do Sul. Semina: Ciências Agrárias, Londrina, v. 30. n. 1, p. 1061-1072, 2009.

CARDOSO, W. S. et al. Variabilidade de genótipos de milho quanto à composição de carotenóides nos grãos. Pesquisa Agropecuária Brasileira, Brasília, v. 44, n. 2, p. 164-173, 2009.
CARGNELUTTI FILHO, A. et al. Comparação de métodos de agrupamento para o estudo da divergência genética em cultivares de feijão. Ciência Rural, Santa Maria, v. 38, n. 8, p. 2138-2145, 2008.

CIA, E. et al. Reação de cultivares e linhagens de algodoeiro às principais doenças que ocorrem em regiões produtoras do Brasil. Revista Ceres, Viçosa, v. 55, n. 6, p. 518-524, 2008.

CIA, E.; SALGADO, C. L. Doenças do algodoeiro (Gossypium spp.). In: KIMATI, H. et al. (Eds.). Manual de fitopatologia. Piracicaba: Agronômica Ceres, 2005. v. 4, cap. 6 p. 40-55.

CORREA, A. M.; GONÇALVES, M. C. Divergência genética em genótipos de feijão comum cultivados em Mato Grosso do Sul. Revista Ceres, Viçosa, v. 59, n. 2, p. 206-212, 2012.

CRUZ, C. D.; CARNEIRO, P. C. S. Modelos biométricos aplicados ao melhoramento genético. 1. ed. Viçosa, MG: UFV 2003. 579 p.

CRUZ, C. D. Programa Genes: Biometria. 1. ed. Viçosa, MG: UFV,2006. 382 p.

CRUZ, C. D.; REGAZZI, A. J.; CARNEIRO, P. C. $\mathrm{S}$. Modelos biométricos aplicados ao melhoramento genético. 4. ed. Viçosa, MG: UFV, 2012. 514 p.

DALLACORT, R. et al. Distribuição das chuvas no município de Tangará da Serra, médio norte do estado do Mato Grosso, Brasil. Acta Scientiarum Agronomy, Maringá, v. 33, n. 2, p. 193-200, 2011.

ECHER, F. R. et al. Estresse hídrico induzido por manitol em cultivares de algodão. Revista Ciência Agronômica, Fortaleza, v. 41, n. 4, p. 638-645, 2010 .

ELIAS, H. T. et al. Variabilidade genética em germoplasma tradicional de feijão-preto em Santa Catarina. Pesquisa Agropecuária Brasileira, Brasília, v. 42, n. 10, p. 1443-1449, 2007.

FANG D. D. A microsatellite-based genome-wide analysis of genetic diversity and linkage disequilibrium in Upland cotton (Gossypium hirsutum L.) cultivars from major cotton-growing countries. Euphytica, Wageningen, v. 191, n. 3, p 391-401, 2013

FOOD AND AGRICULTURE ORGANIZATION OF THE UNITED NATIONS - FAO. Faostat database gateway. Disponível em: $<$ http://faostat. fao.org/site/567/default.aspx\#ancor> Acesso em: 21, jun. 2012 . 
FARIAS, F. J. C. et al. Caracteres de importância econômica no melhoramento do algodoeiro. In: BELTRÃO, N. E. M.; AZEVEDO, D. M. P. (Eds.). O agronegócio do algodão no Brasil. Brasília: Embrapa Informação Tecnológica. 2008. v. 2, cap. 13, p. 413-430.

GILIO, T. A. S. Divergência genética em genótipos de algodoeiro e quantificação de danos causados pela mancha de ramularia. 2014. $70 \mathrm{f}$. Dissertação (Mestrado em Genética e Melhoramento de Plantas: Área de concentração em Melhoramento genético vegetal) - Universidade do Estado de Mato Grosso, Tangará da Serra, 2014.

HALLAUER, A. R.; MIRANDA FILHO, J. B. Quantitative genetics in maize breeding. Ames: Iowa State University Press, 1981. 468 p.

HOOGERHEIDE, E. S. S. et al. Correlações e análise de trilha de caracteres tecnológicos e a produtividade de fibra de algodão. Pesquisa Agropecuária Brasileira, Brasília, v. 42, n. 1, p.1401-1405, 2007.

IQBAL, M. J. et al. A genetic bottleneck in the 'evolution under domestication' of upland cotton Gossypium hirsutum L. examined using DNA finger printing. Theoretical and Applied Genetics, Berlin, v. 103, n. 4, p. 547-554, 2001.

KRAUSE, W. et al. Genetic divergence in snap bean based on agronomic traits and resistance to bacterial wilt. Crop Breeding and Applied Biotechnology, Viçosa, v. 9, n. 1, p. 246-252, 2009.

MAHALANOBIS, P. C. On the generalized distance in statistics. Proceedings of National Institute of Science of the India, Calcutta, v. 2, n. 1, p. 49-55, 1936.

MOIANA, L. D. et al. Genetic diversity and population structure of upland cotton Brazilian cultivars (Gossypium hirsutum L. race latifolium H.) using SSR markers. Australian Journal of Crop Science, Queensland, v. 9, n. 2, p. 143-152, 2015

MANTEL, N. The detection of disease clustering and a generalized regression approach. Cancer Research, Philadelphia, v. 27, n. 2, p. 209-220, 1967.

MIRANDA, G. V. et al. Potencial de melhoramento e divergência genética de cultivares de milho-pipoca. Pesquisa Agropecuária Brasileira, Brasília, v. 38, n. 6, p. 681-688, 2003.

MORO, J. R.; SILVEIRA, F. T.; CARGNELUTTI FILHO, A. Dissimilaridade genética em sessenta e quatro linhagens de milho avaliadas para resistência ao complexo enfezamento. Revista de Biologia e Ciência da Terra, Campina Grande, v. 7, n. 1, p. 153-160, 2007.

RODRIGUES, H. C. A. et al. Avaliação da diversidade genética entre acessos de mamoneira (Ricinus communis L.) por meio de caracteres morfoagronômicos. Revista Ceres, Viçosa, v. 57, n. 6, p. 773-777, 2010.

SHANER, G., FINNEY, R. E. The effect of nitrogen fertilization on the expression of slow mildewing resistence in knox wheat. Phytopathology, St. Paul, v. 67, n. 1 , p. 1051-1056, 1977.

SIMON, G. A., KAMADA, T.; MOITEIRO, M. Divergência genética em milho de primeira e segunda safra. Semina: Ciências Agrárias, Londrina, v. 33, n. 2, p. 449-458, 2012.

SINGH, D. The relative importance of characters affecting genetic divergence. Indian Journal of Genetic and Plant Breeding, New Delhi, v. 41, n. 2, p. 237-245, 1981 .

SOKAL, R. R.; ROHLF, F. J. The comparison of dendrograms by objective methods. Taxon, Berlin, v. 11, n. 1, p.30-40, 1962.

SOUSA, D. M. G.; LOBATO, E. Cerrado: correção do solo e adubação. Planaltina: Embrapa Cerrados, 2004. $416 \mathrm{p}$

SUINAGA, F. A.; BASTOS C. S.; RANGEL L. E. $\mathrm{P}$. Multivariate analisis of genetic divergence in cotton. Revista Brasileira de Oleaginosas e fibrosas, Campina Grande, v. 9, n. 1/3, p. 931-937, 2005.

TAMURA, K. et al. Molecular Evolutionary Genetics Analysis using Maximum Likelihood, Evolutionary Distance, and Maximum Parsimony Methods. Molecular Biology and Evolution, Oxford, v. 28, n. 10, p. 2731-2739, 2011.

TYAGI, P, et al. Genetic diversity and population structure in the US Upland cotton (Gossypium hirsutum L.). Theorical and Applied Genetics, Berlin, v. 127, n. 2, p. 283-295, 2014.

VAZ PATTO, M. C. et al. Assessing the genetic diversity of Portuguese maize germplasm using microsatellite markers. Euphytica, Wageningen, v. 137, n. 1, p. 63-72, 2004.

VILELA-MORALES, E. A.; VALOIS A. C. C. Recursos genéticos vegetais autóctones e seus usos no desenvolvimento sustentável. Cadernos de Ciência e Tecnologia, Brasília, v. 17, n. 2, p. 11-42, 2000. 
WENDEL, J. F.; ALBERT V.A. Phylogenetics of the cotton genus (Gossypium): Character-State Weighted Parsimony Analysis of chloroplast DNA restriction site data and its systematic and biogeographic implications. Systematic Botany. Mexico City, v. 17, n. 1, p. 115-143, 1992.

ZUIN, G. C. et al. Divergência genética entre acessos de mandioca-de-mesa coletados no município de Cianorte, região Noroeste do Estado do Paraná. Semina: Ciências Agrárias, Londrina, v. 30, n. 1, p. 21-30, 2009. 